\title{
Factors influencing the commercialisation of cloning in the pork industry
}

\author{
S.L. Pratt', E.S. Sherrer ${ }^{2}$, D.E. Reeves ${ }^{2}$, and S.L. Stice ${ }^{1}$ \\ 'Department of Animal and Dairy Science, 425 River Road, Edgar Rhodes Animal and Dairy Science \\ Complex, Athens, GA 30602; ${ }^{2}$ Novocell Inc, Ceorgia Bio-business Center, Athens, GA 30602; \\ ${ }^{3}$ Department of Large Animal Medicine, College Of Veterinary Medicine, University of Ceorgia, \\ Athens, CA 30602
}

Production of cloned pigs using somatic cell nuclear transfer (SCNT) is a repeatable and predictable procedure and multiple labs around the world have generated cloned pigs and genetically modified cloned pigs. Due to the integrated nature of the pork production industry, pork producers are the most likely to benefit and are in the best position to introduce cloning in to production systems. Cloning can be used to amplify superior genetics or be used in conjunction with genetic modifications to produce animals with superior economic traits. Though unproven, cloning could add value by reducing pig-to-pig variability in economically significant traits such as growth rate, feed efficiency, and carcass characteristics. However, cloning efficiencies using SCNT are low, but predictable. The inefficiencies are due to the intrusive nature of the procedure, the quality of oocytes and/or the somatic cells used in the procedure, the quality of the nuclear transfer embryos transferred into recipients, pregnancy rates of the recipients, and neonatal survival of the clones. Furthermore, in commercial animal agriculture, clones produced must be able to grow and thrive under normal management conditions, which include attainment of puberty and subsequent capability to reproduce. To integrate SCNT into the pork industry, inefficiencies at each step of the procedure must be overcome. In addition, it is likely that non-surgical embryo transfer will be required to deliver cloned embryos, and/or additional methods to generate high health clones will need to be developed. This review will focus on the state-of-the-art for SCNT in pigs and the steps required for practical implementation of pig cloning in animal agriculture.

\section{Introduction}

The human population of the world will continue to increase significantly and this will strain animal production systems to produce high quality, nutrient dense protein sources for consumption by the masses. Over the last forty years, the pork industry in the United States has become more efficient and more integrated to meet consumer demand and maintain profit margins. In the United States, pork operations that were greater than or equal to 5,000 animals accounted 
for $27.5 \%$ of the total pig numbers in 1995 , but by 2003 this proportion had increased to $79 \%$. The number and weights of commercial pigs slaughtered continued to increase; 103 million animals with an average live weight of $121.4 \mathrm{~kg}$ were processed in 2004 (the National Agriculture Statistics Service at www.usda.mannlib.cornell.edu). Much of the increase in slaughter numbers can be attributed to the increase in litter size and the increase in the number of litters per animal produced over the years. Some states have placed limits on the expansion of pork production facilities making it difficult for producers to overcome any decrease in profit margin by an increase in animal production. This vertical integration and constraints on expansion has caused producers to seek increased efficiencies through better nutrient, disease, and genetic management. To maintain or increase profit margin, pork producers will be required to become even more efficient and introduce new technologies. However, for industry implementation, new technologies must be cost effective. Somatic cell nuclear transfer (SCNT) is a technology that could be implemented into today's pork production systems to maximize genetic gains in the areas of feed efficiency, growth and carcass quality, if it can be cost effective.

Many discussions of the generation of genetically altered swine by SCNT have focused on the use of these technologies for human health studies (see reviews of Cooper et al., 2002, Denning and Priddle, 2003, Kaiser, 2002, Lai and Prather, 2002, Polejaeva, 2001), but this paper will focus on how SCNT can be applied to the production of pork for human consumption. Cloning for animal agricultural can be divided into 2 objectives. The first is amplification of superior animal genetics through cloning, and includes identification of adults with superior economically relevant genetic traits to be cloned. Therefore, cloning would be conducted using somatic cell cultures established from adult animals. The second objective is to genetically modify pig cells to produce animals with augmented superior economic traits. For this purpose, the use of foetal somatic cells would make the most sense because increased population doublings of these cells are critical to identify cells that have incorporated exogenous DNA into their genome.

\section{Somatic cell nuclear transfer}

The biological materials required for SCNT are matured oocytes (metaphase II or MII), which are used as cytoplast recipients, donor cells, which are used as karyoplast (nuclear) donors, and recipients for transfer of the SCNT embryos generated. Oocytes can be purchased commercially or generated in one's own laboratory by in vitro maturation (Hyun et al., 2003b, Abeydeera et al., 2000, Coy et al., 1999, Funahashi and Day, 1997, Nagai, 2001). Donor cells are obtained from female adult animals as described by Gibbons et al. (2002). We found that decontaminated ear biopsies were easily obtained from either sex, required little specialized equipment, and SCNT results were satisfactory using the same culture conditions as described by Gibbons et al. (2002). Once cell cultures were established, it was routine to amplify the cells, then freeze them for future use using typical laboratory procedures. Recipients of SCNT have typically been gilts because estrous synchronization is easier in gilts, embryo transfer is conducted using surgical procedures, which are also easier to perform on gilts, and gilts are generally available in larger numbers. The SCNT embryos were typically transferred into the recipient gilt on the day the embryos were constructed, however, some were cultured for an extended period of time before transfer into the recipient with the longest period reported being approximately $72 \mathrm{~h}$ (Betthauser et al., 2000, Bondioli et al., 2001, Boquest et al., 2002).

Equipment required for cloning include inverted microscopes with ultra-violet capabilities, micromanipulators, holding pipettes, transfer pipettes, slide warmers, electronic equipment to 
perform fusion and activation, and $\mathrm{CO}_{2}$ incubators for cell, oocyte, and if required, embryo culture. In vitro matured oocytes used for SCNT require a two-step 40-44 h maturation procedure to reach the MII stage. The cumulus is removed and the oocytes' chromatin is stained with Hoechst 33342 for visualization under ultra-violet irradiation. The somatic cells to be used in SCNT are removed from culture and prepared for cloning. The denuded oocytes and cells are then placed in media drops and placed under the microscope for manipulation. First, the first polar body and the MII metaphase plate are removed using the holding pipette to position the egg and the transfer pipette to remove unwanted chromatin. Next, a cell is placed in the transfer pipette, moved through the zona pellucida and placed adjacent to the oocyte. At this point, the couplet of oocyte and donor cell is electrically fused, and then activated. Most labs have used electric pulses for activation (Bondioli et al., 2001, Dai et al., 2002, De Sousa et al., 2002, Lai et al., 2002a, Lai et al., 2002b, Walker et al., 2002). However, Betthauser et al. (2000) and Boquest et al. (2002) used the kinase inhibitor, 6-dimethylaminopurine, in a chemical activation procedure with similar success in producing clones. At this point, the embryos were cultured or transferred into recipient gilts.

Obviously, there are many steps and reagents in the cloning procedure which require optimization, thus, much debate has arisen about the critical parameters required for successful SCNT. The SCNT process is inefficient due to the lack of understanding of 1) biological reagent quality and 2) how the reagents interact. Other than knowing the stage of the oocyte used, little is known about oocyte quality for SCNT or other assisted reproductive technologies. In addition, researchers have suggested that the somatic cell cultures used in SCNT impact the outcome. It is possible that the interaction of the donor cell nucleus with the oocyte environment is the key factor in determining cloning efficiencies and for SCNT to be implemented on a significant scale in the swine industry, efficiencies must become greater. Finally, failure of proper donor nucleus/oocyte interaction most likely results in generation of clones that do not survive the neonatal period, or fail to become structurally sound adults capable of reproduction.

\section{The efficiencies of pig cloning}

Prather and coworkers (1989) were the first to demonstrate that nuclear transfer could produce cloned offspring in the pig, and this was accomplished by using embryonic blastomeres in the process. It was not until 1996 that researchers produced the first cloned animal from adult somatic cells by SCNT. Campbell, et al. (1996), used sheep adult somatic cells for SCNT, and demonstrated that an adult somatic cell was effectively reprogrammed by the oocyte's machinery and allowed normal foetal development (Campbell et al., 1996). Use of a somatic cell from an adult of known genetic merit is much more desirable, from a genetic improvement stand point, since the performance of the clones' progeny may be accurately predicted. The first report of cloned pigs using adult somatic cells in SCNT was published by Polejaeva and coworkers (2000), but it involved two highly cost prohibitive steps: 1) utilization of in vivo produced Mll oocytes, and 2) generation of in vivo produced zygotes with both being used in a double nuclear transfer. Subsequently, in the same year, two different laboratories utilized a single nuclear transfer of the somatic donor cell to an enucleated MII oocyte to produce cloned pigs. Both laboratories used foetal somatic cells in the SCNT procedure (Betthauser et al., 2000, Onishi et al., 2000), however, Betthauser et al. (2000) established that in vitro matured oocytes, obtained from gilt or sow ovaries, were effective in the SCNT procedure. The efficiencies in producing cloned embryos from these 3 studies, defined as the number of live offspring divided by the total number of SCNT embryos transferred, ranged from 0.9 to $1.4 \%$. 
Since the year 2000, there were, at least, 15 other reports of the production of cloned pigs with efficiencies ranging from 0.1 to $5.5 \%$ (Bondioli et al., 2001; Boquest et al., 2002; Dai et al., 2002; De Sousa et al., 2002; Lai et al., 2002a; Lai et al., 2002b; Park et al., 2001; Park et al., 2002; Ramsoondar et al., 2003; Walker et al., 2002; Martin et al., 2004; Hyun et al., 2003; Lee et al., 2003; Harrison et al., 2004; Kolber-Simonds et al., 2004). The efficiencies of cloning, the donor cell type and oocyte type used in the studies referenced are shown in Table 1.

Table 1. Reports published between the years 2000 and 2004 illustrating successful cloning of pigs, and the efficiency (the percentage of live offspring obtained from the total number of SCNT embryos transferred). All donor cell types were somatic in origin from foetal, neonatal or adult sources.

\begin{tabular}{|c|c|c|c|}
\hline Oocyte source' & Donor cell type ${ }^{2}$ & Efficiency & Author \\
\hline In vitro gilt & Foetal somatic & $1.2 \%$ & Betthauser et al., 2000 \\
\hline In vitro sow & Foetal somatic & $1.4 \%$ & Betthauser et al., 2000 \\
\hline In vivo gilt & Foetal somatic & $0.9 \%$ & Onishi et al., 2000 \\
\hline In vivo gilt & Adult somatic & $1.2 \%^{3}$ & Polejaeva et al., 2000 \\
\hline In vivo gilt & 4 mo. old male somatic & $0.9 \%$ & Bondioli et al., 2001 \\
\hline In vitro & Transgenic foetal somatic & $1.6 \%+$ & Park et al., 2001 \\
\hline In vivo gilt & Foetal somatic & $0.3 \%$ & Boquest et al., 2002 \\
\hline In vitro sow & Targeting foetal somatic & $0.2 \% 5$ & Dai et al., 2002 \\
\hline In vivo gilt & Foetal somatic & $0.2 \%$ & De Sousa et al., 2002 \\
\hline In vitro gilt and sow & Targeted foetal somatic & $2.1 \% 6$ & Lai et al., 2002a \\
\hline In vitro gilt & Transgenic foetal somatic & $0.5 \%$ & Lai et al., 2002b \\
\hline In vitro gilt & 4 day neonatal somatic & $0.9 \%$ & Park et al., 2002 \\
\hline In vitro gilt & Foetal somatic & $5.5 \%$ & Walker et al., 2002 \\
\hline In vitro gilt & Non- and transgenic foetal somatic & $0.0 \%$ & Hyun et al., 2003 \\
\hline In vitro sow & Non- and transgenic foetal somatic & $0.1 \%$ & Hyun et al., 2003 \\
\hline In vivo gilt & Adult somatic & $0.6 \%$ & Lee et al., 2003b \\
\hline In vitro/ln vivo gilt & Targeted and non-targeted somatic & $0.3 \%$ & Ramsoondar et al., 2003 \\
\hline In vitro sow & Targeted foetal somatic & $1.9 \%$ & Harrison et al., 2004 \\
\hline In vitro sow & Transgenic foetal somatic & 0.06 to $0.1 \%$ & Kolber-Simonds et al., 2004 \\
\hline In vitro sow & Transgenic neonatal somatic & 0.06 to $0.1 \%$ & Kolber-Simonds et al., 2004 \\
\hline In vivo gilt & Transgenic foetal somatic & No information & Martin et al., 2004 \\
\hline
\end{tabular}

'In vitro indicates oocytes that were matured under culture conditions, and in vivo defines oocytes harvested surgically from animals post ovulation. Gilt defines either prepubertal or cycling animals, while sow indicates adult sources.

${ }^{2}$ Donor cell sources are presented without regard to any tissue differences from which the cultures were isolated. Somatic defines the cells as either fibroblast, epithelial, or mixed in nature. Clones were produced from cells synchronized in $\mathrm{GO} / \mathrm{G} 1$ by serum starvation or contact inhibition, proliferating, or synchronized to $\mathrm{G} 2 / \mathrm{M}$ phase of the cell cycle with no discernable difference due to treatment.

${ }^{3}$ Piglets were produced by a double nuclear transfer procedure and the efficiency is calculated from all transferred SCNT embryo generated in this manner regardless of cell line.

${ }^{4}$ Effciency was calculated by including all SCNT embryos transferred to each gilt; however, piglets were produced only by the retroviral transduced cell line.

${ }^{5}$ Efficiency was calculated only from and including all three cell lines reported at the time of press and not on predicted numbers reported due to farrow.

'The efficiency listed is only from the gilts that were reported to have farrowed. The total number of embryos transferred including animals not progressing to term are not included.

'The efficiencies listed are based on the range of oocytes transferred to each recipient and the total number of recipients reported. 


\section{Oocyte impact on cloning}

For the large scale production of SCNT embryos that will be required for production of pig clones for agricultural purposes, oocytes, which will be cytoplast recipients, must be cost effective, easily available, reliable, and, possibly most important, disease free. The earliest successes with SCNT in pigs came with the use of in vivo matured oocytes (Polejaeva et al., 2000). in fact, the first reports of success from most laboratories resulted from using in vivo matured oocytes (Bondioli et al., 2001, Boquest et al., 2002, De Sousa et al., 2002, Onishi et al., 2000, Martin $M$ et al., 2004, Lee et al., 2003b), with efficiencies of producing live offspring ranging from 0.1 to $1.2 \%$. To obtain in vivo matured oocytes, prepubertal or cycling gilts were superovulated by injection of PMSG followed 72-82 $\mathrm{h}$ later by injections of hCG with collection of the ovulated MII oocytes after projected ovulation times. Generally, the oocytes were harvested by reverse flushing of the oviduct using surgical procedures. Therefore, it is easy to see that this source of matured oocytes would be fairly expensive. However, the literature shows successful cloning with in vivo matured oocytes and the procedure could be conducted with gilts in high health herds, which alleviates any customer concerns about introduction of diseases from clones produced from these oocytes. In contrast, oocytes obtained from animal ovaries at slaughter, which are generated within one's own laboratory, or cost effectively purchased from several companies that specialize in oocyte production, are a readily available source $(\sim 500,000$ gilts are slaughtered each year in the United States) and are reliable in the production of cloned pigs (Betthauser et al., 2000, Dai et al., 2002, Harrison et al., 2004, Hyun et al., 2003a, Kolber-Simonds et al., 2004, Lai et al., 2002b, Lai et al., 2002a, Walker et al., 2002). Based on reports in the literature, efficiencies of producing live offspring using either in vitro $(0.1$ to $5.5 \%)$ or in vivo $(0.1$ to $1.2 \%)$ matured oocytes are similar. The successful production of clones using in vitro matured oocytes as the cytoplast recipient source in SCNT was a critical step forward in commercializing cloning.

Health status of the collected oocytes is a concern. If produced from high health status donors, in vivo collected oocytes can reduce the risk of disease transfer through the SCNT process. This advantage comes with a cost, however, because in vivo collected oocytes are more costly to produce than those collected at slaughter or purchased. Because of the conditions in which they are collected and the source of the donor animals, in vitro produced oocytes cannot be considered to be disease free.

When using in vitro matured oocytes in assisted reproductive technologies such as SCNT, one should consider whether the oocytes are obtained from gilts or sows. In the United States, pigs are sent to market with a body weight between 114 to $132 \mathrm{~kg}$ and are approximately 7 months of age; therefore few of these animals have attained puberty. Sows are also slaughtered in the United States, but represent only $3 \%$ of all hogs slaughtered. It has been suggested that embryonic development when using assisted reproductive technologies is superior when using sow oocytes. Betthauser et al. (2000) reported a 2-fold higher rate of in vitro embryo development to the blastocyst stage for SCNT embryos generated from sow oocytes $(8 \%)$ than for SCNT embryos generated from gilt oocytes $(4 \%$; Betthauser et al., 2000). In contrast, Hyun et al. (2003a) reported that fewer SCNT blastocysts were generated when using sow oocytes $(36 \%)$ compared to gilt oocytes $(45 \%)$ across 3 different activation treatments $(P<0.05)$, but both the inner cell mass and total cell number for blastocysts were higher for sow oocytes $(P<0.05)$ and only SCNT embryos generated with sow oocytes resulted in cloned offspring. However, the overall efficiency in producing live offspring in this study was 0.0 to $0.1 \%$ for SCNT embryos generated with gilt or sow oocytes, respectively. Higher cloning efficiencies with either sow or gilt oocytes have been obtained by others. In vitro embryo development data from IVF studies support the report of Betthauser, et al. (2000) and develop- 
ment to the blastocyst stage was also reported to be higher for sow oocytes by Sherrer et al. (2004). Therefore, it may be advantageous to use sow oocytes for in vitro maturation, if they can be easily obtained.

In summary, the use of in vitro matured oocytes obtained from prepubertal gilts, rather than sows, will most likely continue to be the major source for any assisted reproductive technologies due to availability. In addition, the cost of generating in vitro oocytes for SCNT is lower than that of generating in vivo oocytes. Also, there is no clear advantage to using in vivo matured oocytes vs. in vitro matured in the SCNT procedure. However, the industry concern about biosecurity issues related to the use of in vitro matured oocytes in SCNT must be addressed. While procedures for effective decontamination of embryos have been established, no such procedures exist for oocytes. Also, these procedures would not be as effective for NT embryos because the intrusive procedure ruptures the zona pellucida, allowing entry of infectious agents into the embryo.

\section{Donor cell effects}

Many topics involving the impact of the donor cell on the success of the SCNT process, such as type of the somatic cell (fibroblast versus epithelial), stage of the cell cycle at which the cell is transferred, or length of time in culture are still open for discussion. As shown in Table 1, only two studies reported the use of adult somatic cells in the cloning procedure (Lee et al., 2003b, Polejaeva et al., 2000). However, both of these studies were conducted in a manner to circumvent either electrical fusion and/or chemical activation of the cloned embryos. The first involved a two-step process where standard SCNT procedures were conducted, but following pronuclear formation, the karyoplast was transferred to an enucleated zygote (Polejaeva et al., 2000). The second involved injection of the whole cell into the cytoplast recipient, eliminating the need for fusion, but the donor cell/oocyte couplets were electrically activated (Lee et al., 2003b).

Several comparisons between cell types of foetal versus adult cells have been conducted, but the end points of these experiments were typically blastocyst formation during in vitro culture of embryos. De Sousa et al. (2002) compared foetal fibroblasts to cumulus (adult epithelial) cells as karyoplast donors and found no differences in development to the blastocyst stage when using either in vivo or in vitro matured oocytes as the cytoplast recipient $(0$ to $10 \%$ across all experimental combinations). Lee et al. (2003a) found higher levels of in vitro development using foetal fibroblasts $(15.9 \%)$ compared to adult fibroblasts, cumulus or oviductal cells $(3.1$ to $7.9 \%)$. The cell culture itself may impact cloning success. Kuhholzer et al. (2001) found that different cell cultures developed from the same foetal source exhibited differences in fusion and blastocyst formation rates, and Park et al. (2002) also reported cell line variation with non-retroviral transduced cells exhibiting higher in vitro blastocyst formation rates (15.9\%) than retroviral transduced cells $(9.3 \%)$. Interestingly, the reverse was true for blastocyst cell number. Virally transduced cells were superior to non-transduced cells $(39.9 \pm 4.1$ to $28.9 \pm 1.0$ cells per blastocyst, respectively), and upon co-transfer of the two different SCNT embryos into recipients, only cells that were subjected to viral transduction produced offspring (Park et al., 2001). This is consistent with literature citing generation of cloned pigs where more than one cell line was used in SCNT. In the first report of cloned pigs, all of the progeny was generated from only two of the eight cell lines used (Polejaeva et al., 2000), and later only one of three targeted cell lines produced offspring (Dai et al., 2002).

Our bovine cloning efforts indicate that stage of cell cycle may be important in the success of SCNT (Gibbons et al., 2002), and the cell cycle can be synchronized to the G0/G1 stage by either serum starvation treatment, culturing cells to confluence where contact inhibition pro- 
duces quiescence, or by incubation with a cell cycle inhibitor. Serum starvation and contact inhibition resulted in efficiencies in producing live offspring from somatic cells (transgenic or non-transgenic) ranging from 0.3 to $5.5 \%$ (Betthauser et al., 2000, Boquest et al., 2002, Walker et al., 2002) and 0.1 to $0.9 \%$ (De Sousa et al., 2002, Hyun et al., 2003a, Onishi et al., 2000) for cells synchronized to $\mathrm{G} 0 / \mathrm{G} 1$ by either contact inhibition or serum starvation, respectively. To date, the use of cell cycle inhibitors to synchronize to the G0/G1 stage in pigs has not been reported. However, cells synchronized to the $62 / \mathrm{M}$ stage of the cell cycle were successful in producing transgenic cloned pigs at an efficiency of $0.5 \%$ (Lai et al., 2002b). Proliferating cells also produced cloned swine (Bondioli et al., 2001, Lai et al., 2002a).

Since the first report of cloned pigs in 2000 (Polejaeva et al., 2000), probably the most significant progress has been made in the area of genetic modification. Surprisingly, the efficiency with which cloned pigs were generated from targeted cells was not much lower than those reported for non-manipulated cells with the range being 0.2 to $2.1 \%$ (Dai et al., 2002, Lai et al., 2002a, Ramsoondar et al., 2003). Kolber-Simonds et al. (2004) generated null clones for the galactosyl- $\alpha-1,3-$ galactose gene, which is responsible for the hyper-acute rejection response for xenotransplants in primates, using hemizygous targeted cells for that gene. They used a novel antibody/compliment selection system to eliminate cells, which expressed the undesired epitope, and thereby, enriched for cells that had undergone a spontaneous rearrangement resulting in cells null for the gene (Kolber-Simonds et al., 2004). These cells produced null progeny from SCNT. Generation of targeted cells resulted after using a promoter trap technique for the galactosyl- $\alpha$-1,3-galactose gene. However, one could envision the same strategies to generate transgenic swine for agricultural purposes. For instance, the porcine reproductive and respiratory syndrome virus (PRRSV) binds to cell membrane proteins (receptors) followed by endocytosis involving clathrin coated pits. Therefore, the gene encoding the membrane-integrated protein(s) to which PRRSV binds could be targeted to generate PRRSV resistant animals.

Currently, it is unclear if stage of the cell cycle, type of donor cell (fibroblast or epithelial), source of donor cell (foetal or adult), or length of time in culture impact SCNT efficiencies, but a good argument can be made from our observations and other personal communications that differences in primary cell cultures can impact cloning results. This is probably due to the presence or absence of epigenetic modifications in certain cultures that allow for effective reprogramming of the donor karyoplast by the cytoplast recipient.

\section{Clone survival and quality}

Some have speculated that the reprogramming process, or the lack thereof, is the most critical issue to consider in SCNT. Reprogramming is an often used, but poorly understood, term applied to alteration of somatic cell chromatin and gene expression, such that it becomes capable of generating all possible cell types in the living organism (totipotency). Events, which culminate in reprogramming, are nuclear swelling after NT, movement of oocyte proteins into the donor cell nucleus and replacement of donor nuclear proteins, global demethylation, and re-lengthening of the telomeres. Regulation of methylation of the zygote and embryo genome has been implicated in aberrant gene expression (Biniszkiewicz et al., 2002, Bourc'his et al., 2001, Dean et al., 1998, Kang et al., 2001a, Kang et al., 2002). Methylation is thought to play a critical role in the process of genomic imprinting (Brannan and Bartolomei, 1999, Young and Fairburn, 2000), which generally involves suppression of allelic expression of one parent. In general, hypomethylation of a gene allows it to be expressed while hypermethylation represses expression of that allele (Kikyo and Wolffe, 2000). At least 40 different genes have been identified and classified as imprinted (Kikyo and Wolffe, 2000, Young and Fairburn, 
2000), and most are expressed in a developmental and/or tissue specific manner. IGF2, the IGF2 receptor, and Mash2 regulate foetal growth and/or placental growth and function (Caspary et al., 1999, Guillemot et al., 1995, Reik et al., 2000). At the time of fertilization, the oocyte DNA is hypomethylated, however, the sperm DNA is hypermethylated. After syngamy, the entire genome is demethylated throughout development to the blastocyst stage for all mammalian species examined (Dean et al., 2001), after which certain genes are remethylated. The remethylation of a gene blocks its expression. However, Kang et al. (2000b) observed that methylation of the PRE-1 short interspersed sequence element and the centromeric satellite sequences of SCNT embryos, as determined by bisulfite-sequencing technology, was similar to normally fertilized embryos, but this does not eliminate the possibility of altered gene expression by porcine SCNT embryos. It may only indicate species-specific imprinting mechanisms. The failure to adequately reprogram the donor nucleus in SCNT results in altered gene expression that manifests itself in the form of aberrant placentation, foetal and neonatal mortality, and phenotypic anomalies of cloned offspring.

The survival, structural integrity and reproductive capabilities of cloned pigs have been overlooked in much of the literature, but is a major concern for pork production companies. Both inferior survival and quality are associated with inadequate donor nuclei reprogramming. The health risk of neonatal clones of ruminants and rodents are well documented (Shimozawa N. et al., 2002, Sinclair et al., 2000, Tanaka et al., 2001) and include factors, such as abnormal foetal size (De Sousa et al., 2001, Eggan et al., 2001, Gibbons et al., 2002, Heyman et al., 2002, Wells et al., 2004, Wilson et al., 1995, Young et al., 1998), and neonatal physiological problems including respiratory, cardiovascular, and renal ailments (Gibbons et al., 2002, Hill et al., 1999). Unfortunately, little of this type of information is available from literature describing the cloning of pigs, but may be some of the most important observations required to implement SCNT in the swine industry. Table 2 lists the authors and their observations of low birth weights, cleft palate, anal atresia, and musculoskeletal anomalies in cloned pigs (Lai et al., 2002a, Walker et al., 2002). Walker and coworkers (2002) observed only one abnormality in the 28 clones they produced using non-genetically modified foetal fibroblast cells.

Table 2. Results from four studies, which reported anomalies for cloned offspring born alive.

\begin{tabular}{|c|c|c|c|c|}
\hline $\begin{array}{l}\text { \#NT } \\
\text { piglets }\end{array}$ & Birth wt $(\mathrm{kg})$ & $\begin{array}{l}\text { Placental } \\
\text { wt (g) }\end{array}$ & $\begin{array}{l}\text { Observed anomalies } \\
\text { (\# of piglets affected) }\end{array}$ & Author \\
\hline 5 & 0.8 to 1.7 & - & $\begin{array}{l}\text { Contracture of flexor tendons in forelimbs (1) } \\
\text { Low serum levels for total protein and globulin (5) }\end{array}$ & Park et al., 2001 \\
\hline 7 & 0.3 to 1.1 & 189 to 374 & $\begin{array}{l}\text { Flexure deformity of distal intraphalangeal joint (4) } \\
\text { Dysmaturity at birth (2) } \\
\text { Heart anomalies (3) } \\
\text { Cleft palate (1) } \\
\text { Death (3) }\end{array}$ & Lai et al., 2002 \\
\hline 4 & 0.9 to 1.3 & - & $\begin{array}{l}\text { Congestive heart failure (1) } \\
\text { Abnormally large foreleg with } 3 \text { dew claws (1) } \\
\text { Death (2) }\end{array}$ & Park et al., 2002 \\
\hline 28 & $\begin{array}{l}1.1 \pm 0.2 \text { to } \\
1.4 \pm 0.1^{\prime}\end{array}$ & $\begin{array}{l}227+16 \text { to } \\
290+90^{2}\end{array}$ & Anal atresia (1) & $\begin{array}{l}\text { Walker et al., } \\
2002\end{array}$ \\
\hline
\end{tabular}

'Birth weights are the means generated from 4 litters of piglets.

zPlacental weights are the means generated from 3 litters of piglets. 
The other workers utilized genetically modified cells produced either by retroviral transduction (Park et al., 2001; Park et al., 2002), or by gene targeting (Lai et al., 2002a). Birth weights were recorded in all 4 studies. Lai et al. (2004) utilized miniature swine cells. One would expect slightly lower birth weights compared to the other reports, but it is clear that the piglet exhibiting an approximately $0.3 \mathrm{~kg}$ birth weight was low even for miniature swine (Lai et al., 2002a). Park and coworkers observed lower birth weights for clones than reported for the herd average of approximately $1.5 \mathrm{~kg}$ (Park et al., 2001, Park et al., 2002). The two studies, in which placental weights were recorded, showed similarities in weights, however, no morphological data were presented (Park et al., 2002; Walker et al., 2002).

Obviously, when clones attain adulthood, they must be capable of reproduction. Martin et al. (2004) clearly demonstrated that the reproductive capacity of both males and females, as well as the sex ratio, litter size, birth weights, and postnatal gain of their litters were similar among cloned and control pigs. The reproductive capabilities of cloned pigs reported by Martin et al. (2004) are consistent with those reported by other researchers for other species, in that the clones were fertile and fertility did not differ from conventionally produced animals (Enright et al., 2002, Heyman et al., 2004, Martin et al., 2004, Pace et al., 2002, Shimozawa et al., 2002, Tamashiro et al., 2003, Wells et al., 2004).

\section{Implementation of SCNT}

Genetic pyramids are commonly used in the swine industry. Pyramids have a genetic source, commonly referred to as the nucleus, which generates maternal and terminal cross lines to produce the commercial market pigs at the bottom of the pyramid. Health status within pyramids is greatly treasured, particularly near the top. To capture value, the pyramid is multilayered. This multi-layering is beneficial because it provides the opportunity to produce large numbers of breeding animals from a single nucleus. However, this multi-layering has the negative effect of diluting the genetic potential selected for at the nucleus. While selection pressure for valuable traits is high in the nucleus herds, the requirement to produce large numbers of pigs for market at the bottom of the pyramid necessitates that selection pressure be relaxed by the amplification of hog numbers through this pyramid. With each subsequent mating, up to $50 \%$ of the genetic gain captured in the nucleus herd level may be lost, and the time interval before any of the genetic gain reaches the market hog level typically takes 3 to 5 years. Cloning implemented on a commercial basis would have great value because it would allow the capture of the full genetic value by eliminating the need for downstream multiplication and the subsequent dilution of genetic benefit. It would also reduce the risk of introducing a new disease within the pyramid because it would reduce the possible points for disease entry.

As previously discussed, SCNT is still inefficient and needs further improvements and/or the development of new technologies to make implementation of cloning a reality on a large scale in the swine industry. To further complicate matters, a means to deliver cloned embryos or cloned offspring into standard swine production operations needs to be developed. Currently, most laboratories generate SCNT embryos, which are surgically transferred into a recipient gilt shortly after activation. To minimize disease risks in cloned pigs, three techniques are proposed. Introduction of the cloned piglets into a sterile environment by way of Caesarian section (hysterotomy) followed by rearing in a specific pathogen free (SPF) environment removes the potential for disease exposure of the piglet during the birth process and subsequent exposure to disease agents that the sow may be harboring. Another technique, referred to as "snatch farrowing," requires immediate removal of the piglet from the sow and her environment at parturition followed by rearing in an SPF facility. The third approach is referred to as isowean ${ }^{\odot}$, 
in which piglets are farrowed and weaned from the sow at a very early age (7-14 days of age). This approach relies on maternal protection to prevent disease in the piglets. The first two choices would most likely produce the best results; however, the labor required for rearing the pigs in this manner would be expensive. The third choice would require less labor, but the piglets would be at a greater risk for disease exposure, and significant testing of the animals would be required. The alternative would be to ship embryos to the sites where the clones are to be placed and reared. However, many of these sites would not have the facilities to perform surgical embryo transfer. Therefore, for cloning to be widely implemented, mechanisms to ship SCNT pig embryos, and non-surgical embryo transfer must to be developed. Currently, non-surgical embryo transfer has not been very successful in the pig. However, several laboratories have reported the birth of piglets from the procedure (Li et al., 1996, Martinez et al., 2001, Durcro-Steverink et al., 2003, Hazeleger and Kemp, 1999, Martinez et al., 2004). The best result reported to date, using a non-surgical embryo transfer procedure, is an $80 \%$ pregnancy rate and litter sizes of 6-7 piglets (Martinez et al., 2004). If repeatable, this is a great accomplishment and bodes well for companies wishing to ship and transfer embryos, or cloned embryos. For this technology to be used in the context of SCNT, it will require embryos to be cultured for an extended period of time before transfer. Therefore, quality swine embryo culturing systems need to be developed.

\section{Conclusion}

In SCNT, the area that has advanced the most is that of genetic modification while cloning efficiencies have remained consistently low. Genetic modification of animals could be used to enhance disease resistance or other economically viable traits. Such a strategy could be implemented with the current technology, but both the industry and consumers would have to accept genetically modified animals in the food chain. Most likely, the first clones utilized in the swine industry will be boars with high genetic merit for production traits. However, pig SCNT is inefficient, and the associated systems, such as embryo culture and non-surgical ET required to implement cloning on a large scale still require much work in the swine industry. However, cloned pigs can be produced predictability and in sufficient numbers to impact pork production operations. This can be done by focusing on the cloning of the top terminal cross boars and/or maternal line boars in the nucleus herd to populate boar studs for production of semen to ship to sow units for Al. Semen from terminal cross boars would be used on commercial sows for production of market hogs, and semen from the cloned maternal line boars would be used to generate the commercial sows. This would maximize genetic gains generated in the nucleus herd by reducing dependence on the standard breeding and multiplication systems now in place, and decrease the time for those genetics to impact commercial swine production by at least 2 years. All of this can be accomplished with the technology as it is today in conjunction with surgical embryo transfer of cloned embryos and SPF rearing of the cloned piglets. The major competitor to the implementation of SCNT in the swine industry would be new technologies developed by the semen production industry. The same strategy could be accomplished by using Al, if technologies were developed to 1) effectively freeze and store boar semen, and 2) extend the number of Al from a single boar collection.

\section{References}

Abeydeera, L. R., Wang, W. H., Cantley, T. C., Rieke, A., Murphy, C. N., Prather, R. S. and Day, B. N. (2000) Development and viability of pig oocytes matured in a protein-free medium containing epidermal growth factor, Theriogenology, 54, 787-97.

Betthauser, 1., Forsberg, E., Augenstein, M., Childs, L., 
Eilertsen, K., Enos, J., Forsythe, T., Golueke, P., Jurgella, G., Koppang, R., Lesmeister, T., Mallon, K., Mell, G., Misica, P., Pace, M., Pfister-Genskow, M., Strelchenko, N., Voelker, G., Watt, S., Thompson, S. and Bishop, M. (2000) Production of cloned pigs from in vitro systems, Nature Biotechnology, 18, 1055-9.

Biniszkiewicz, D., Gribnau, J., Ramsahoye, B., Gaudet, F., Eggan, K., Humpherys, D., Mastrangelo, M. A., Jun, Z., Walter, J. and Jaenisch, R. (2002) Dnmt 1 over expression causes genomic hypermethylation, loss of imprinting, and embryonic lethality, Molecular and Cellular Biology, 22, 2124-35.

Bondioli, K., Ramsoondar, J., Williams, B., Costa, C. and Fodor, W. (2001) Cloned pigs generated from cultured skin fibroblasts derived from a $\mathrm{H}$ - transferase transgenic boar, Molecular Reproduction and Development, 60, 189-95.

Boquest, A. C., Grupen, C. G., Harrison, S. J., Mcllfatrick, S. M., Ashman, R. J., d'Apice, A. J. and Nottle, M. B. (2002) Production of cloned pigs from cultured foetal fibroblast cells, Biology of Reproduction, 66, 1283-7.

Bourc'his, D., Le Bourhis, D., Patin, D., Niveleau, A., Comizzoli, P., Renard, J. P. and Viegas-Pequignot, E. (2001) Delayed and incomplete reprogramming of chromosome methylation patterns in bovine cloned embryos, Current Biology, 11, 1542-6.

Brannan, C. I. and Bartolomei, M. S. (1999) Mechanisms of genomic imprinting, Current Opinion in Genetics and Development, 9, 164-70.

Campbell, K. H., McWhir, J., Ritchie, W. A. and Wilmut, I. (1996) Sheep cloned by nuclear transfer from a cultured cell line, Nature, 380, 64-6.

Caspary, T., Cleary, M. A., Perlman, E. J., Zhang, P., Elledge, S. J. and Tilghman, S. M. (1999) Oppositely imprinted genes p57(Kip2) and igf2 interact in a mouse model for Beckwith-Wiedemann syndrome, Genes and Development, 13, 3115-24.

Cooper, D. K., Gollackner, B. and Sachs, D. H. (2002) Will the pig solve the transplantation backlog?, Annual Review of Medicine, 53, 133-47.

Coy, P., Ruiz, S., Romar, R., Campos, I. and Gadea, J. (1999) Maturation, fertilization and complete development of porcine oocytes matured under different systems, Theriogenology, 51, 799-812.

Dai, Y., Vaught, Y. D., Boone, J., Chen, S. H., Phelps, C. J., Ball, S., Monahan, J. A., Jobst, P. M., McCreath, K. J., Lamborn, A. E., Cowell-Lucero, J. L., Wells, K. D., Colman, A., Polejaeva, I. A. and Ayares, D. L. (2002) Targeted disruption of the alpha1,3galactosyltransferase gene in cloned pigs, Nature Biotechnology, 20, 251-5.

De Sousa, P. A., Dobrinsky, J. R., Zhu, J., Archibald, A. L., Ainslie, A., Bosma, W., Bowering, J., Bracken, J., Ferrier, P. M., Fletcher, J., Gasparrini, B., Harkness, L., Johnston, P., Ritchie, M., Ritchie, W. A., Travers, A., Albertini, D., Dinnyes, A., King, T. J. and Wilmut, I. (2002) Somatic cell nuclear transfer in the pig: control of pronuclear formation and integration with improved methods for activation and maintenance of pregnancy, Biology of Reproduction, 66, 642-50.

De Sousa, P. A., King, T., Harkness, L., Young, L. E., Walker, S. K. and Wilmut, I. (2001) Evaluation of gestational deficiencies in cloned sheep fetuses and placentae, Biology of Reproduction, 65, 23-30.

Dean, W., Bowden, L., Aitchison, A., Klose, J., Moore, T., Meneses, J. J., Reik, W. and Feil, R. (1998) Altered imprinted gene methylation and expression in completely ES cell- derived mouse fetuses: association with aberrant phenotypes, Development, 125, 2273 82.

Dean, W., Santos, F., Stojkovic, M., Zakhartchenko, V., Walter, J., Wolf, E. and Reik, W. (2001) Conservation of methylation reprogramming in mammalian development: aberrant reprogramming in cloned embryos, Proceedings of the National Academy of Science U S A, 98, 13734-8.

Densing, C. and Priddle, H. (2003) New frontiers in gene targeting and cloning: success, application and challenges in domestic animals and human embryonic stem cells, Reproduction, 126, 1-11.

Durcro-Steverink, Peters, C. G. W., Maters, C. C., Hazeleger, W. and Merks, J. W. M. (2003) Reproduction results and offspring performance after non-surgical embryo transfer in pigs, Theriogenology.

Eggan, K., Akutsu, H., Loring, J., Jackson-Grusby, L.., Klemm, M., Rideout, W. M., 3rd, Yanagimachi, R. and Jaenisch, R. (2001) Hybrid vigor, foetal overgrowth, and viability of mice derived by nuclear cloning and tetraploid embryo complementation, Proceedings of the National Academy of Science $U$ $S$ A, 98, 6209-14.

Enright B.P., Taneja M, Schreiber D, Riesen J, Tian XC, Fortune JE and X., Y. (2002) Reproductive characteristics of cloned heifers derived from adult somatic cells, Biology of Reproduction, 66, 291-6.

Funahashi, H. and Day, B. N. (1997) Advances in in vitro production of pig embryos, Journal of Reproduction and fertility Supplement, 52, 271-83.

Gibbons, J., Arat, S., Rzucidlo, J., Miyoshi, K., Waltenburg, R., Respess, D., Venable, A. and Stice, S. (2002) Enhanced survivability of cloned calves derived from roscovitine-treated adult somatic cells, Biology of Reproduction, 66, 895-900.

Guillemot, F., Caspary, T., Tilghman, S. M., Copeland, N. G., Gilbert, D. J., Jenkins, N. A., Anderson, D. J., Joyner, A. L., Rossant, J. and Nagy, A. (1995) Genomic imprinting of Mash2, a mouse gene required for trophoblast development, Nature Genetics, 9, 235-42.

Harrison, S., Boquest, A., Grupen, C., Faast, R., Guildolin, A., Giannakis, C., Crocker, L., Mcilfatrick, S., Ashman, R., Wengle, J., Lyons, I., Tolstoshev, P., Cowan, P., Robins, A., O'Connell, P., D'Apice, A. J. and Nottle, M. (2004) An efficient method for producing alpha(1,3)-galactosyltransferase gene knockout pigs, Cloning Stem Cells, 6, 327-31.

Hazeleger, W. and Kemp, B. (1999) State of the art in pig embryo transfer, Theriogenology, 51, 81-90.

Heyman $Y$, Richard C, Rodriguez-Martinez $H$, Lazzari G, Chavatte-Palmer P, Vignon $X$ and C., G. (2004) 
Zootechnical performance of cloned cattle and offspring: preliminary results., Cloning Stem Cells, 6, 111-20.

Meyman, Y., Chavatte-Palmer, P., LeBourhis, D., Camous, S., Vignon, X. and Renard, J. P. (2002) Frequency and occurrence of late-gestation losses from cattle cloned embryos, Biology of Reproduction, 66, 6-13.

Hill, J. R., Roussel, A. J., Cibelli, J. B., Edwards, J. F., Hooper, N. L., Miller, M. W., Thompson, J. A., Looney, C. R., Westhusin, M. E., Robl, I. M. and Stice, S. L. (1999) Clinical and pathologic features of cloned transgenic calves and feluses $(13$ case studies), Theriogenology, 51, 1451-65.

Hyun, S., Lee, G., Kim, D., Kim, H., Lee, S., Nam, D., Jeong, Y., Kim, S., Yeom, S., Kang, S., Han, J., Lee, B. and Hwang, W. (2003a) Production of nuclear transfer-derived piglets using porcine foetal fibroblasts transfected with the enhanced green fluorescent protein, Biology of Reproduction, 69, 1060-8.

Hyun, S. H., Lee, G. S., Kim, D. Y., Kim, H. S., Lee, S. H., Kim, S., Lee, E. S., Lim, J. M., Kang, S. K., Lee, B. C. and Hwang, W. S. (2003b) Effect of maturation media and oocytes derived from sows or gilts on the development of cloned pig embryos, Theriogenology, 59, 1641-9.

Kaiser, J. (2002) Xenotransplantation. Cloned pigs may help overcome rejection, Science, 295, 25-7.

Kang, Y. K., Koo, D. B., Park, J. S., Choi, Y. H., Chung, A. S., Lee, K. K. and Han, Y. M. (2001a) Aberrant methylation of donor genome in cloned bovine embryos, Nature Genetics, 28, 173-7.

Kang, Y. K., Koo, D. B., Park, J. S., Choi, Y. H., Kim, H. N., Chang, W. K., Lee, K. K. and Han, Y. M. (2001b) Typical demethylation events in cloned pig embryos. Clues on species-specific differences in epigenetic reprogramming of a cloned donor genome, Journal of Biological Chemistry, 276, 39980-4.

Kang, Y. K., Park, J. S., Koo, D. B., Choi, Y. H., Kim, 5. U., Lee, K. K. and Han, Y. M. (2002) Limited demethylation leaves mosaic-type methylation states in cloned bovine pre-implantation embryos, The EMBO Journal, 21, 1092-100.

Kikyo, N. and Wolffe, A. P. (2000) Reprogramming nuclei: insights from cloning, nuclear transier and heterokaryons Journal of Cell Science, 113 ( Pt 1), 11-20.

Kolber-Simonds, D., Lai, L., Watt, S. R., Denaro, M., Arn, S., Augenstein, M. L., Betthauser, J., Carter, D. B., Greenstein, J. L., Hao, Y., Im, G. S., Liu, Z., Mell, G. D., Murphy, C. N., Park, K. W., Rieke, A., Ryan, D. J. J., Sachs, D. H., Forsberg, E. J., Prather, R. S. and Hawley, R. I. (2004) Production of a-1,3galactosyltransferase null pigs by means of nuclear transfer with fibroblasts bearing loss of heterozygosity mutations, Proceedings of the National Academy of Science U S A., 101, 7335-7340.

Kuhholzer, B., Hawley, R. J., Lai, L., Kolber-Simonds, D. and Prather, R. S. (2001) Clonal lines of transgenic fibroblast cells derived from the same fetus result in different development when used for nuclear transfer in pigs, Biology of Reproduction, 64, 1695-8.
Lai, L., Kolber-Simonds, D., Park, K. W., Cheong, H. T., Greenstein, J. L., Im, G. S., Samuel, M., Bonk, A., Rieke, A., Day, B. N., Murphy, C. N., Carter, D. B., Hawley, R. J. and Prather, R. S. (2002a) Production of alpha-1,3-galactosyltransferase knockout pigs by nuclear Iransfer cloning, Science, 295, 1089-92.

Lai, L., Park, K. W., Cheong, H. T., Kuhholzer, B., Samuel, M., Bonk, A., Im, G. S., Rieke, A., Day, B. N., Murphy, C. N., Carter, D. B. and Prather, R. S. (2002b) Transgenic pig expressing the enhanced green fluorescent protein produced by nuclear transfer using colchicine-treated fibroblasts as donor cells, Molecular Reproduction and Development, 62, 300-6.

Lai, L. and Prather, R. S. (2002) Progress in producing knockout models for xenotransplantation by nuclear transfer, Annals of Medicine, 34, 501-6.

Lee, G. S., Hyun, S. H., Kim, H. S., Kim, D. Y., Lee, S. H., Lim, J. M., Lee, E. S., Kang, S. K., Lee, B. C. and Hwang, W. S. (2003a) Improvement of a porcine somatic cell nuclear transfer technique by optimizing donor cell and recipient oocyte preparations, Theriogenology, 59, 1949-57.

Lee, J. W., Wu, S. C., Tian, X. C., Barber, M., Hoagland, T., Riesen, J., Lee, K. H., Tu, C. F., Cheng, W. T. and Yang, $X$. (2003b) Production of cloned pigs by wholecell intracytoplasmic microinjection, Biology of Reproduction, 69, 995-1001.

Li, J., Rieke, A., Day, B. N. and Prather, R. S. (1996) Technical note: porcine non-surgical embryo transfer, Journal of Animal Science, 74, 2263-8.

Martin M, Adams C and B., W. (2004) Pre-weaning performance and health of pigs born to cloned (foetal cell derived) swine versus non-cloned swine, Theriogenology, 62, 113-122.

Martinez, E. A., Caamano, J. N., Gil, M. A., Rieke, A., McCauley, T. C., Cantley, T. C., Vazquez, J. M., Roca, J., Vazquez, J. L., Didion, B. A., Murphy, C. N., Prather, R. S. and Day, B. N. (2004) Successful nonsurgical deep uterine embryo transfer in pigs, Theriogenology, 61, 137-46.

Martinez, E. A., Vazquez, J. M., Roca, J., Lucas, X., Gil, M. A. and Vazquez, J. L. (2001) Deep intrauterine insemination and embryo transfer in pigs, Reproduction Supplement, 58, 301-11.

Nagai, T. (2001) The improvement of in vitro maturation systems for bovine and porcine oocytes, Theriogenology, 55, 1291-301.

Onishi, A., Iwamoto, M., Akita, T., Mikawa, S., Takeda, K., Awata, T., Hanada, H. and Perry, A. C. (2000) Pig cloning by microinjection of foetal fibroblast nuclei, Science, 289, 1188-90.

Pace M.M., Augenstein M.L., Betthauser J.M., Childs L.A., Eilertsen K.J., Enos J.M., Forsberg E.J., Golueke P.J., Graber D.F., Kemper J.C., Koppang R.W., Lange G., Lesmeister T.L., Mallon K.S., Mell G.D., Misica P.M., Pfister-Genskow M., Strelchenko N.S., Voelker G.R., Watt S.R. and M.D., B. (2002) Ontogeny of cloned cattle to lactation., Biology of Reproduction., 67, 334-9.

Park, K. W., Cheong, H. T., Lai, L., Im, G. S., Kuhholzer, B., Bonk, A., Samuel, M., Rieke, A., Day, B. N., 
Murphy, C. N., Carter, D. B. and Prather, R. S. (2001) Production of nuclear transfer-derived swine that express the enhanced green fluorescent protein, Animal Biotechnology, 12, 173-81.

Park, K.W., Lai, L., Cabot, R., Sun, Q.Y., Wu, G., Rucker, E., Durtschi, D., Bonk, A., Samuel, M., Rieke, A., Day, B.N., Murphy, C.N., Carter, D.B., and Prather, R.S. (2002). Mosaic gene expression in nuclear transfer-derived embryos and the production of cloned transgenic pigs from ear-derived fibroblasts. Biology of Reproduction, 66, 1001-5.

Polejaeva, I. A. (2001) Cloning pigs: advances and applications, Reproduction Supplement, 58, 293-300.

Polejaeva, I. A., Chen, S. H., Vaught, T. D., Page, R. L., Mullins, J., Ball, S., Dai, Y., Boone, J., Walker, S., Ayares, D. L., Colman, A. and Campbelt, K. H. (2000) Cloned pigs produced by nuclear transfer from adult somatic cells, Nature, 407, 86-90.

Prather, R. S., Sims, M. M. and First, N. L. (1989) Nuclear transplantation in early pig embryos, Biology of Reproduction, 41, 414-8.

Ramsoondar, J. J., Machaty, Z., Costa, C., Williams, B. 1., Fodor, W. L. and Bondioli, K. R. (2003) Production of alpha 1,3-galactosyltransferase-knockout cloned pigs expressing human alpha 1,2fucosylosyltransferase, Biology of Reproduction, 69 , 437-45.

Reik, W., Constancia, M., Dean, W., Davies, K., Bowden, L., Murrell, A., Feil, R., Walter, J. and Kelsey, G. (2000) Igf2 imprinting in development and disease, International journal of Developmental Biology, 44, 145-50.

Sherrer, E. S., Rathbun, T. J. and Davis, D. L. (2004) Fertilization and blastocyst development in oocytes obtained from prepubertal and adult pigs, Journal of Animal Science, 82, 102-8.

Shimozawa N., Ono Y., Kimoto S., Hioki K., Araki Y., Shinkai Y., Kono T. and M., I. (2002) Abnormalities in cloned mice are not transmitted to the progeny., Genesis., 34, 203-7.

Sinclair, K. D., Young, L. E., Wilmut, I. and McEvoy, T. C. (2000) in-utero overgrowth in ruminants following embryo culture: lessons from mice and a warning to men, Human Reproduction, 15 Suppl 5, 68-86.

Tamashiro K.L., Wakayama T., Yamazaki Y., Akutsu H., Woods S.C., Kondo S., Yanagimachi R. and R.R., S. (2003) Phenotype of cloned mice: development, behavior, and physiology., Exp Biol Med, 228, 1193 200.

Tanaka, S., Oda, M., Toyoshima, Y., Wakayama, T., Tanaka, M., Yoshida, N., Hattori, N., Ohgane, J., Yanagimachi, R. and Shiota, K. (2001) Placentomegaly in cloned mouse concepti caused by expansion of the spongiotrophoblast layer, Biology of Reproduction, 65, 1813-21.

Walker, S. C., Shin, T., Zaunbrecher, G. M., Romano, J. E., Johnson, G. A., Bazer, F. W. and Piedrahita, J. A. (2002) A highly efficient method for porcine cloning by nuclear transfer using in vitro-matured oocytes, Cloning Stem Cells, 4, 105-12.

Wells DN, Forsyth JT, McMillan V and B., O. (2004) The health of somatic cell cloned cattle and their offspring., Cloning Stem Cells, 6, 101-10.

Wilson, J. M., Williams, J. D., Bondioli, K. R., Looney, C., Westhusin, M. and McCalla, D. F. (1995) Comparison of birth weight and growth characteristics of bovine calves produced by nuclear transfer (cloning), embryo transfer and natural mating, Animal Reproduction Science, 38, 73-83.

Young, L. E. and Fairburn, H. R. (2000) Improving the safety of embryo technologies: possible role of genomic imprinting, Theriogenology, 53, 627-48.

Young, L. E., Sinclair, K. D. and Wilmut, I. (1998) Large offspring syndrome in cattle and sheep, Reviews of Reproduction, 3, 155-63. 